\title{
A Comparative Study on Dimensions of Role Efficacy between Top and Lower Management of Universities in Rajasthan
}

\author{
Chaudhary A. K. ${ }^{1}$, Jain $\mathrm{N}^{2}$
}

\section{ABSTRACT:}

The purpose of the present research work is to compare role efficacy of middle and lower management employees of universities of Rajasthan. Respondents were directly contacted for filling up the standard questionnaire of Role Efficacy Scale, developed by Dr. Udai Pareek. The ten dimensions of role efficacy namely (Centrality, Self-role integration, Proactivity, Creativity, Inter-role linkage, Helping relationship, Super ordination, Influence, Personal growth and Coordination ) were analysed through t-test. The results conclude that there is significant difference on dimension such as self role integration, proactivity, creativity, inter role linkage, helping relationship, personal growth and coordination of role efficacy of top and lower management. The significance of the study is based on the challenges facing higher education and to improve their academic standard through role efficacy of top and lower level management.

Keywords: Role efficacy, Top management, Lower management.

University is an institution of higher education and research which grants academic degrees in a variety of subjects and provides both undergraduate education and postgraduate education. The university's employees played different roles in the university to execute various tasks. They have required proficiency to execute various tasks so we have to needed study of role efficacy of employees of universities. Role efficacy mean's a person's capacity for producing a desired result or effect; effectiveness. In other words it means potential effectiveness of an individual occupying a particular role in university.

\section{Review of Literature}

According to Miller, Woehr, Hudspeth (2001), work ethics can be seen in the dimensions of morality in work place, self-reliance, hard work, delay of gratification, work centrality and so on. The present study is interested in work centrality as an attitudinal aspect of work ethic.

\footnotetext{
${ }^{1}$ Senior Lecturer, Department of Psychology, Government Meera Girls College, Udaipur (Raj.)

${ }^{2}$ Research Scholar, Faculty of Management, Pacific University, Udaipur.
} 


\section{A Comparative Study on Dimensions of Role Efficacy between Top and Lower Management of Universities in Rajasthan}

Objectives of the Study: The objectives of the present research are as follows:

1. To study the role efficacy in the Top and Lower Management employees of universities of Rajasthan.

2. To study the various dimensions of role efficacy namely Centrality, Self-role integration, Proactivity, Creativity, Inter-role linkage, Helping relationship, Super ordination, Influence, Personal growth and Coordination of university employees.

3. To compare the various dimensions of role efficacy between Top and Lower Management employees of universities.

Methodology: First of all the head of the institutions were contacted and after taking permission for data collection, respondents were contacted at their comfort zone of time. Then the Role Efficacy Scale questionnaires were distributed and collected after 45 minutes. Thereafter scoring was done with the help of manual and interpretation was done. Thereafter t-test was applied for the comparison of top and lower management university employees in the context of various dimensions of role efficacy.

Tool: RES (Role Efficacy Scale) by Udai Pareek was used. The scale consists of 10 dimensions of role efficacy namely Centrality, Self-role integration, Proactively, Creativity, Inter-role linkage, Helping relationship, Super ordination, Influence, Personal growth and Coordination. The test is reliable (reliable coefficient 0.68 ) and valid (validity coefficient 0.51 )

\section{Research Design}

Data were collected from 270 employees drawn from Public, Private and Deemed Universities. For testing the differences on present role efficacy between Top and Lower management of employees of Universities, the distribution of sample is as follows: Top management $=180$ and Lower management $=90$.

Sample: The sample consisted of a total number of 180 top management (academic) and 90 employees lower management from six universities of Rajasthan. 


\section{ANALYSIS AND DATA INTERPRETATION}

There will be no significant difference between Top and Lower Management regarding dimensions of role efficacy namely Centrality, Self-role integration, Proactivity, Creativity, Inter-role linkage, Helping relationship, Super ordination, Influence, Personal growth and Coordination of University's employee.

Comparison of Top and Lower Management on dimensions of Role efficacy

\begin{tabular}{|c|c|c|c|c|c|c|c|}
\hline Dimensions & Type of Management & $\mathbf{N}$ & Mean & S.D. & Mean Diff & $\mathbf{t}$ & p value \\
\hline \multirow[t]{2}{*}{ Centraility } & Top & 180 & 2.13 & .994 & \multirow[t]{2}{*}{.156} & \multirow[t]{2}{*}{1.161} & \multirow[t]{2}{*}{.247} \\
\hline & Lower & 90 & 1.98 & 1.122 & & & \\
\hline \multirow[t]{2}{*}{ Self-role integration } & Top & 180 & 2.94 & 1.282 & \multirow[t]{2}{*}{.772} & \multirow[t]{2}{*}{3.758} & \multirow[t]{2}{*}{.000} \\
\hline & Lower & 90 & 2.17 & 2.079 & & & \\
\hline \multirow[t]{2}{*}{ Proactivity } & Top & 180 & 2.02 & 1.307 & \multirow[t]{2}{*}{.500} & \multirow[t]{2}{*}{2.748} & \multirow[t]{2}{*}{.006} \\
\hline & Lower & 90 & 1.52 & 1.595 & & & \\
\hline \multirow[t]{2}{*}{ Creativity } & Top & 180 & 2.87 & 1.073 & \multirow[t]{2}{*}{.617} & \multirow[t]{2}{*}{3.550} & \multirow[t]{2}{*}{.000} \\
\hline & Lower & 90 & 2.26 & 1.771 & & & \\
\hline \multirow[t]{2}{*}{ Inter-role linkage } & Top & 180 & 2.79 & 1.251 & \multirow[t]{2}{*}{.911} & \multirow[t]{2}{*}{4.362} & \multirow[t]{2}{*}{.000} \\
\hline & Lower & 90 & 1.88 & 2.177 & & & \\
\hline \multirow[t]{2}{*}{ Helping relationship } & Top & 180 & 2.51 & 1.676 & \multirow[t]{2}{*}{.872} & \multirow[t]{2}{*}{3.391} & \multirow[t]{2}{*}{.001} \\
\hline & Lower & 90 & 1.63 & 2.510 & & & \\
\hline \multirow[t]{2}{*}{ Super ordination } & Top & 180 & 1.57 & 1.473 & \multirow[t]{2}{*}{.400} & \multirow[t]{2}{*}{1.947} & \multirow[t]{2}{*}{.053} \\
\hline & Lower & 90 & 1.17 & 1.807 & & & \\
\hline \multirow[t]{2}{*}{ Influence } & Top & 180 & 2.12 & 1.363 & \multirow[t]{2}{*}{.372} & \multirow[t]{2}{*}{1.964} & \multirow[t]{2}{*}{.051} \\
\hline & Lower & 90 & 1.74 & 1.660 & & & \\
\hline \multirow[t]{2}{*}{ Personal Growth } & Top & 180 & 2.27 & 1.217 & \multirow[t]{2}{*}{.344} & \multirow[t]{2}{*}{2.037} & .043 \\
\hline & Lower & 90 & 1.92 & 1.478 & & & \\
\hline Coordination & Top & 180 & 3.42 & 1.182 & .800 & 4.223 & .000 \\
\hline & Lower & 90 & 2.62 & 1.917 & & & \\
\hline
\end{tabular}

The above table shows that ' $\mathrm{t}$ ' score for centrality dimension of role efficacy is found to be 1.161 which is insignificant at 0.05 level it infers that there is no significant difference on centraility dimension of role efficacy between top and lower management. The above table indicates that ' $t$ ' score for self-role integration dimension of role efficacy is found to be 3.758 which is significant at 0.01 level it infers that there is significant differences on self-role integration dimension of role efficacy between top and lower management. The above table reflects that 't' score for proactivity dimension of role efficacy is found to be 2.748 which is significant at 0.01 level it infers that there is significant differences on proactivity dimension of role efficacy between top and lower management. The above table depicts that ' $\mathrm{t}$ ' score for 


\section{A Comparative Study on Dimensions of Role Efficacy between Top and Lower Management of Universities in Rajasthan}

creativity dimension of role efficacy is found to be 3.550 which is significant at 0.01 level it infers that there is significant differences on creativity dimension of role efficacy between top and lower management. The above table reveals that ' $t$ ' score for inter-role linkage dimension of role efficacy is found to be 4.362 which is significant at 0.05 level it infers that there is significant differences on inter-role linkage dimension of role efficacy between top and lower management. The above table observes that ' $t$ ' score for helping relationship dimension of role efficacy is found to be 3.391 which is significant at 0.01 level it infers that there is significant differences on helping relationship dimension of role efficacy between top and lower management. The above table refers that ' $t$ ' score for super ordination dimension of role efficacy is found to be 1.947 which is insignificant at 0.05 level it infers that there is no significant difference on super ordination dimension of role efficacy between top and lower management. The above table exhibits that ' $t$ ' score for influence dimension of role efficacy is found to be 1.964 which is insignificant at 0.05 level it infers that there is no significant difference on influence dimension of role efficacy between top and lower management. The above table refers that ' $\mathrm{t}$ ' score for personal growth dimension of role efficacy is found to be 2.037 which is significant at 0.05 level it infers that there is insignificant differences on personal growth dimension of role efficacy between top and lower management. The above table exhibits that ' $t$ ' score for coordination dimension of role efficacy is found to be 4.223 which is significant at 0.01 level it infers that there is significant differences on coordination dimension of role efficacy between top and lower management.

\section{Interpretation}

- Centrality dimension of Role Efficacy Top and Lower management do not differs significantly on Centrality dimension of organizational role efficacy. It may be due to both types of management have similar level of potential effectiveness.

- Self Role Integration dimension of Role Efficacy Top and Lower management differs significantly on Self Role Integration dimension of organizational role efficacy. It may be due to Top management have more strength, experiences, and special skills in comparison to lower management to make Self Role Integration.

- Proactivity dimension of Role Efficacy Top and Lower management differs significantly on Proactivity dimension of organizational role efficacy. Top management had significantly more proactivity from Lower management it may be due to Top management executes all decision with take initiative then Lower management of university level.

- Creativity dimension of Role Efficacy Top and Lower management differs significantly on Creativity dimension of organizational role efficacy. Top management had significantly more Creativity from Lower management it may be due to Top management having more opportunities to be creative and they used new and unconventional ways to solving problems then Lower management.

- Inter Role Linkage dimension of Role Efficacy Top and Lower management differs significantly on Inter Role Linkage dimension of organizational role efficacy. Top 


\section{A Comparative Study on Dimensions of Role Efficacy between Top and Lower Management of Universities in Rajasthan}

management had significantly more Inter Role Linkage from Lower management it may be due to Top management executes important role in the university by nature organization.

- Helping Relationship dimension of Role Efficacy Top and Lower management differs significantly on Helping Relationship dimension of organizational role efficacy. Top management had significantly more Helping Relationship from Lower management it may be due to Top management help to Lower management.

- Super ordination dimension of Role Efficacy Top and Lower management do not differs significantly on Super ordination dimension of organizational role efficacy at university level. It may be due to they have serve at similar level of systems and groups beyond the organization.

- Influence dimension of Role Efficacy Top and Lower management do not differ significantly on Influence dimension of organizational role efficacy. It may be due to they have similar power to Influence larger section of society.

- Personal Growth dimension of Role Efficacy Top and Lower management differs significantly on Personal Growth dimension of organizational role efficacy. Top management had significantly more Personal Growth in comparision to Lower management it may be due to Top management employees have more opportunities for personal growth.

- Coordination dimension of Role Efficacy Top and Lower management differ significantly on Coordination dimension of organizational role efficacy. Top management had significantly more Coordination from Lower management employees it may be due to Top management are super position holders to listen the employee's problem and solve them

\section{Findings}

The Top management perform more better on self-role integration, Proactivity, Creativity, Helping relationship, inter-role linkage, Personal Growth and Coordination in comparison of Lower management.

\section{Conclusions}

There is significant difference between Top and Lower management on dimension Self-role integration, Proactivity, Creativity, Inter-role linkage, Helping Relationship, Personal Growth and Coordination.

\section{Recommendations}

1. Lower management required to maintain all seven subsystems i.e. self-role integration, proactivity, creativity, inter-role linkage, helping relationship, personal growth and coordination.

2. A separate program for lower management is the dire need of the time.

3. Lower management requires to improved self-role integration, proactivity, creativity, interrole linkage, helping relationship, personal growth and coordination dimensions of role efficacy. Which can done be through orientation program.

Limitation of the Study: This research is limited to the top and lower management of educational sector of Rajasthan. This study relied on self report and surveyed data.

\section{References}

Miller, M; Woehr, D. J; \& Hudspeth, N. (2001). The meaning and measurement of work Ethic: Construction and Initial Validation of Multidimensional inventory. Journal of vocational Behaviour, 59, 1 -39. 